\title{
Wilt Disease of Tara (Caesalpinia spinosa Molina Kuntz) in Nursery in the Inter Andean Valley of Cochabamba, Bolivia
}

\author{
Mario Coca Morante \\ Escuela de Ciencias Forestales (ESFOR), Departamento de Fitotecnia, Facultad de Ciencias Agrícolas y Pecuarias (FCAyP) \\ “Martin Cárdenas”, Universidad Mayor de San Simón, Cochabamba, Bolivia \\ Email: agr.mcm10@gmail.com
}

How to cite this paper: Morante, M.C. (2018) Wilt Disease of Tara (Caesalpinia spinosa Molina Kuntz) in Nursery in the Inter Andean Valley of Cochabamba, Bolivia. American Journal of Plant Sciences, 9, 1963-1973.

https://doi.org/10.4236/ajps.2018.99142

Received: October 5, 2017

Accepted: August 27, 2018

Published: August 30, 2018

Copyright (C) 2018 by author and Scientific Research Publishing Inc. This work is licensed under the Creative Commons Attribution International License (CC BY 4.0).

http://creativecommons.org/licenses/by/4.0/

\begin{abstract}
Tara (Caesalpinia spinosa Molina Kuntz) is a native plant of the Bolivian Andes. A number of projects have promoted the cultivation of this species over the last 20 years, in efforts to make use of its medicinal, food and industrial properties. However, as tara plantations have grown, so too has the incidence of disease affecting the species, leading to economic losses. The aim of the present work was to identify the causal agent of wilting in tara, and to determine the incidence of the disease in nursery-grown plants. Three experimental plots $\left(R_{1}-R_{3}\right)$ were established in plantlet production bedsat the ESFOR nursery in order to assess the incidence of wilting. Plant spacing was 1 $\times 1 \mathrm{~m}$. At the two leaf stage, samples of diseased and apparently healthy plants were taken to the laboratory for the isolation of pathogens. Both the apparently healthy and diseased plants gave rise to the same kinds of fungal colony on PDA. Microscopic examination revealed microconidia, macroconidia, phialides and chlamydospores suggesting the causal agent to be Fusarium oxysporum. Over the (up to) 84-day period following thinning, the incidence of wilting for 2010 was $\mathrm{R}_{1}=2.56 \%, \mathrm{R}_{2}=3.15 \%$ and $\mathrm{R}_{3}=2.22 \%$ per 14 days, and for 2013 it was $R_{1}=1.24 \%, R_{2}=2.45 \%$ and $R_{3}=2.13 \%$ per 14 days; the apparent infection rates for 2010 were $r_{R 1}=0.0003 /$ day, $r_{R 2}=0.0003 /$ day and $r_{R 3}$ $=0.0003 /$ day, and for 2013 they were $r_{R 1}=0.0003 /$ day, $r_{R 2}=0.0004 /$ day and $\mathrm{r}_{\mathrm{R} 3}=0.0003 /$ day. These values are characteristic of monocyclic epiphytic fungi such as F. oxysporum.
\end{abstract}

\section{Keywords}

Soil Pathogens, Monocyclic Epiphytic Fungi, Disease Intensity, Fusarium oxysporum 


\section{Introduction}

Tara (Caesalpinia spinosa Molina Kuntz) is a native forest plant of the Andes, and occurs in Peru, Bolivia, Ecuador, Colombia, Venezuela and northern Chile [1]. In Bolivia it grows naturally in the dry valleys of the Andes (Interandean Valles) at $1000-3000 \mathrm{~m}$. Its content in tannins, gallic acid and other compounds afford it medicinal, food and industrial properties [1] [2]. Since 2005, a number of projects with international aid funding have promoted the cultivation of tara in Bolivia [2], and the nursery production of tara plantlets has becomean important activity. Currently, several public and private nurseries in the Cochabamba Valleys supply young tara plants to the area's growers and those beyond [2]. However, while tara was thought to be affected by few diseases and pests (with the exception of powdery mildew in some areas) [2], disease has recently become a problem, with both nursery and plantation plants affected [3]. One of those causing problems in the Cochabamba Valley and other areas of Bolivia is wilting. This disease is associated with significant field losses. Indeed, in a five year-old plantation at La Aguada (Valle Grande, Dept. of Santa Cruz, Bolivia), incidence rates of $26 \%$ and $45 \%$ were recorded in two plots in 2012 [4].

Fusarium is among the top 10 crop-affecting fungal genera in the world [5], with different species affecting different crops [6] [7]. The genus has also been associated with wilting in tara, although the causal species has remained unknown [3]. The candidate specie, Fusarium oxysporum Schlechtis, a soil pathogen causes vascular wilting in a wide range of plants [5]. The classic symptoms include vascular discoloration, dwarfism, defoliation and death [8]. It can cause production problems at nurseries, but plantlets may be asymptomatic when shipped out. The propagules of $F$. oxysporum can survive in the soil for long periods in the absence of a host [9]. When young field plants are infected, death may occur after a few years. This type of epiphytic fungus is characterised as monocyclic [10]. A reliable estimate of disease intensity (incidence plus severity) is vital if it is to be managed, and the spatial distribution of the disease needs to be modelled for surveillance procedures to be developed [11]. The aim of the present work was to identify the causal species of wiltdisease in tara, and to assess the incidence of the disease among nursery plants.

\section{Materials and Methods}

\subsection{Study Area}

The present work was performed at the nursery of the Escuela de Ciencias Forestales (ESFOR; the School of Forestry Science), Facultad de Ciencias Agrícolas $y$ Pecuarias "Martin Cárdenas" at the Universidad Mayor de San Simón, Cochabamba, Bolivia. The ESFOR nursery lies at $17^{\circ} 27^{\prime} \mathrm{S}$ and $66^{\circ} 09^{\prime} \mathrm{W}$, and at an altitude of $2750 \mathrm{~m}$, in the Tunari National Park in the Cercado Province within the Dept. of Cochabamba. The climate of the area is dry and mild; the mean minimum temperature is $10^{\circ} \mathrm{C}$, the mean maximum is $30^{\circ} \mathrm{C}$, and the mean rainfall is $450 \mathrm{~mm}$. 


\subsection{Identification of the Causal Agent of Wilting in Tara}

Samples of tara plantlets aged 4 months were collected in a random fashion from nursery production beds; this sampling thus included plants that were apparently healthy (Figure 1, right) and that showed wilting (Figure 1, left) (Figure 1). In the laboratory, the roots were washed under running water to remove the soil, and then rinsed in sterile, distilled water (Figure $1(\mathrm{~b})$ ). Root sections $(0.5 \mathrm{~cm}$ long) were then taken, disinfected in $70 \%$ alcohol, rinsed again in sterile, distilled water, and placed on potato dextrose agar (PDA) (Liofilchem s.r.l. Bacteriology Products) containing streptomycin (two replicates per sample). They were then incubated for $72 \mathrm{~h}$ at $24^{\circ} \mathrm{C}$ under $24 \mathrm{~h}$ periods of light/dark/light. Fungal identification was performed by light microscopy; mycelium samples were mounted in lactophenol with methylene blue, and identifications made using the keys of Leslie and Summerell [6] and Summerell, Salleh and Leslie [6] [7].

\subsection{Determination of Incidence in Nurseries}

In September 2010, and again in October 2013, three experimental plots were established in taraplantlet production beds containing a peat/black/earth-silt (1:2:1) substrate. The latter had received no disinfection treatment (the habitual practice in nurseries). Seeds were supplied by the BASFOR's Banco de Semillas Forestales (Forestry Seed Bank). After the plantsemerged they were thinned into black plastic bags $(15 \times 8 \mathrm{~cm})$ containing a 2:1 black earth/silt substrate (one per bag). At the two-leaf stage the plants were set in the ground, with a spacing of 1 $\times 1 \mathrm{~m}$ as follows: Plot $1\left(\mathrm{R}_{1}\right)$ approximately $600-700$ plantlets, Plot $2\left(\mathrm{R}_{2}\right)$ approximately $700-800$ plantlets and Plot $3\left(R_{3}\right)$ approximately $700-800$ plantlets. Weeding was continuous. Up to two alternating antifungal treatments were provided $\left(\mathrm{Ca}(\mathrm{OH})_{2}\right.$ with sulphur (1 L Sulfocalcic broth)/20 $\mathrm{L} \mathrm{H}_{2} \mathrm{O}$ ), or propiconazole + difeconazole $\left(2 \mathrm{ml}\right.$ of Taspa/1 $\mathrm{L} \mathrm{H}_{2} \mathrm{O}$ ) to control powdery mildew.

Disease incidence was determined as the number of plants with typical symptoms of wilting/total number of plants $\times 100$ [12]. Five assessments were made in 2010 and six in 2013 (once every 14 days). A disease progress curve was plotted, and then linearised usingthe logit function $\operatorname{LN}(y / 1-y)$ [10] [13].

\section{Results}

\subsection{Symptoms of Wilt in Tara}

The characteristic symptoms of wilting in the nursery plants was recorded as initial yellowing of the folioles, in some cases accompanied by a reddening of the foliole underside (Figure 2(a)). Gradually, this reddening became more intense before defoliation (Figure 2(b)). Plantlets with symptoms showed reduced development compared to healthy plants (Figure 2(c), left), and the roots showed signs of decomposition; indeed, there was hardly any secondary root system (Figure 2(c), left). Finally, the xylem took on a dark brown colour at the base of the stem (Figure 2(d)).

Identification of the causal agent 


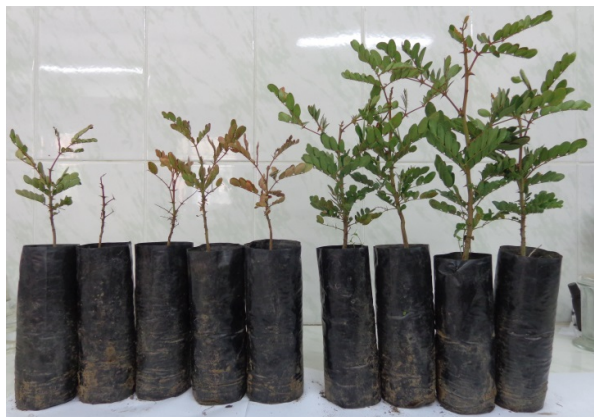

(a)

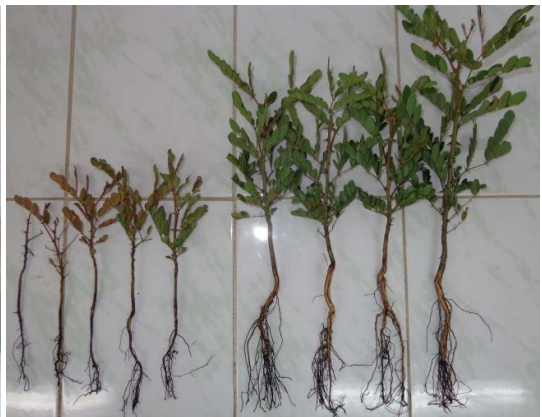

(b)

Figure 1. (a) Left: taraplantlets with symptoms of wilting; Right: apparently healthy plants before planting; (b) Left: diseased tara plants showing their poor root system; Right: apparently healthy plants with much more developed root systems.

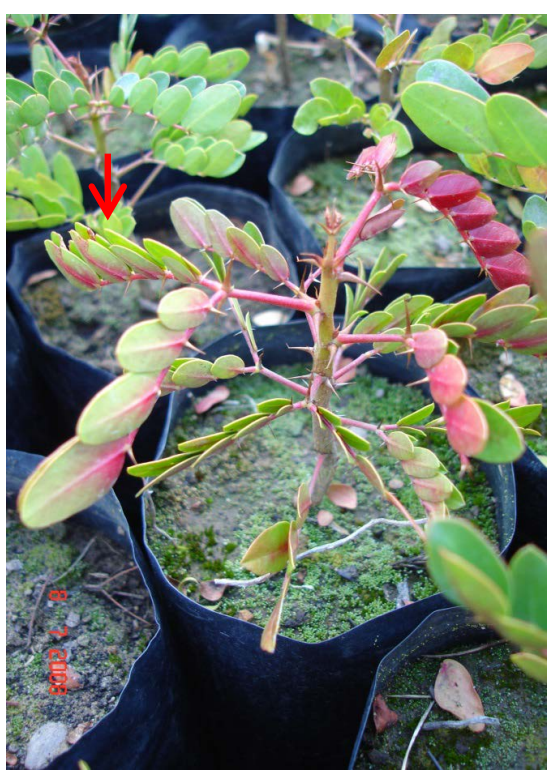

(a)

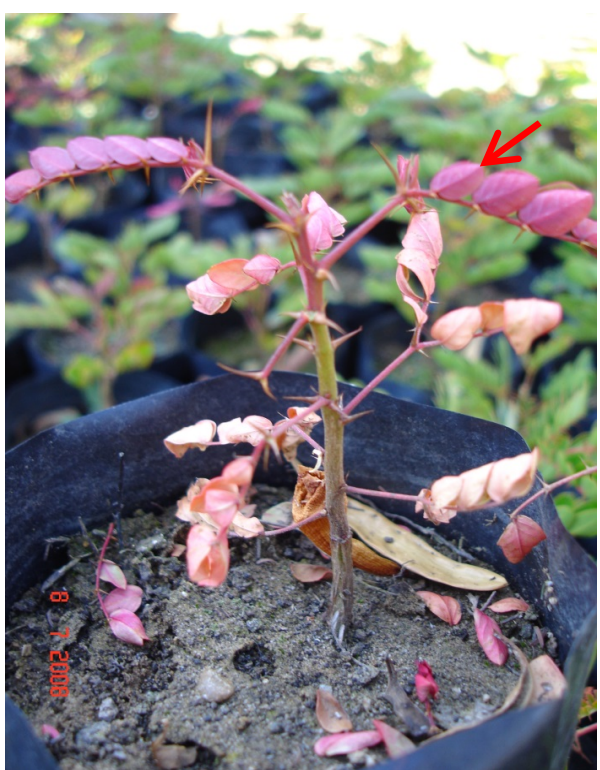

(b)

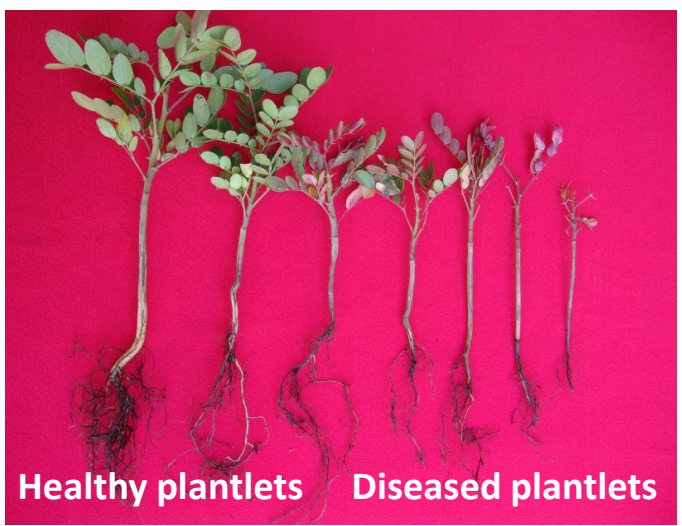

(c)

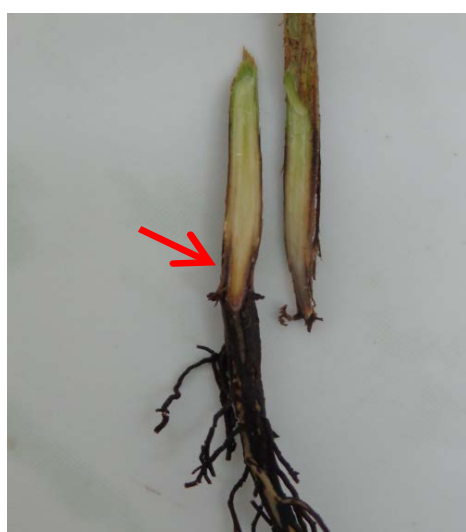

(d)

Figure 2. Characteristic symptoms of wilting in tara. (a) Yellowing (red arrow) of the folioles and defoliation; (b) Reddening (red arrow) of the folioles; (c) Root systems of apparently healthy (left) and diseased plantlets (right); (d) Vascular discoloration (red arrow) at the bottom of the stem in a diseased plantlet. 
All the samples from both the healthy and diseased plants produced mycelia on PDA (Figure 3 and Figure 4). All samples produced mild (Figure 3(b), Figures 3(e)-(h)) to intense (Figure 3(a), Figure 3(c), Figure 3(d)) lilac-coloured colonies, which under the microscope all showed the macro- and microconidia (Figure 5(a)), monophialides with false heads (Figure 5(b)) and chlamydospores (single or in pairs) (Figure 5(c)) characteristic of Fusarium sp. [6] [7].

Some plates showed contaminating colonies of Cylindrocarpon sp. (Figure 3 , red arrows); others showed accompanying colonies of Cylindrocarpon $s p$. (Figure 3, white arrows), as determined from the orange colour of the spores.

\subsection{Disease Incidence}

Figure 6 shows the disease progress curve for the plots $R_{1}, R_{2}$ and $R_{3}$ for 2010 (Figure 6(a)) and 2013 (Figure 6(b), Figure 6(c)). In both years, disease progress was monitored for up to 84 days following thinning. In 2010, the incidence of wilting for was $2.56 \%$ per 14 days for $\mathrm{R}_{1}, 3.15 \%$ per 14 days for $\mathrm{R}_{2}$, and $2.22 \%$ per 14 days for $\mathrm{R}_{3}$ (Figure 6(a)); while in 2013 these values were $1.24 \%, 2.45 \%$ and $2.13 \%$ respectively (Figure $6(\mathrm{c})$ ). The mean incidence $\left(\mathrm{R}_{1}-\mathrm{R}_{3}\right)$ over the monitoring period was $2.64 \%$, for 2010, and 1.94\% for 2013 .

\subsection{Apparent Infection Rate}

Figure 7(a) and Figure 7(b) show the linearized disease progress curves for 2010 and 2013. The apparent infection rates for the three plots in 2010 were: $r_{R 1}$ $=0.0003 /$ day, $r_{R 2}=0.0003 /$ day and $r_{R 3}=0.0003 /$ day, while for 2013 they were $r_{R 1}$ $=0.0003 /$ day, $r_{R 2}=0.0004 /$ day and $r_{R 3}=0.0003 /$ day. The experimental errors for 2010 were $R^{2}=0.98, R^{2}=0.99$ and $R^{2}=0.95$ respectively (Figure $7(a)$ ), and for 2013 they were $\mathrm{R}^{2}=0.99, \mathrm{R}^{2}=0.99$ and $\mathrm{R}^{2}=0.94$ respectively (Figure $7(\mathrm{~b})$ ).

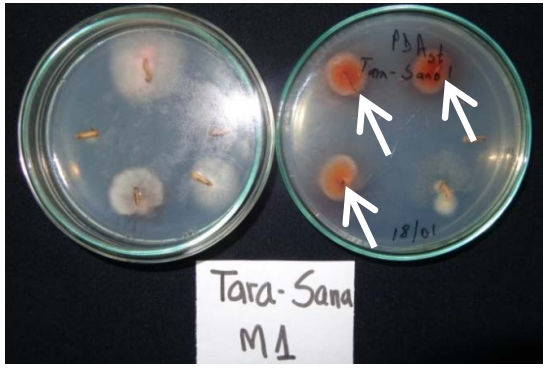

(a)

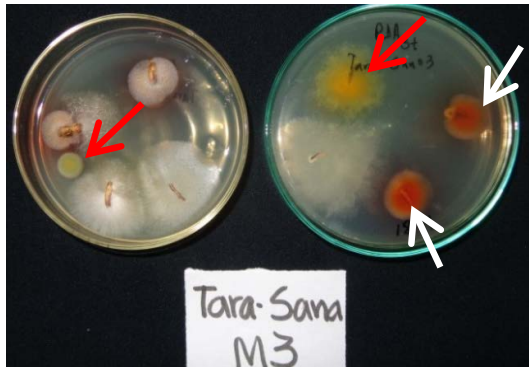

(c)

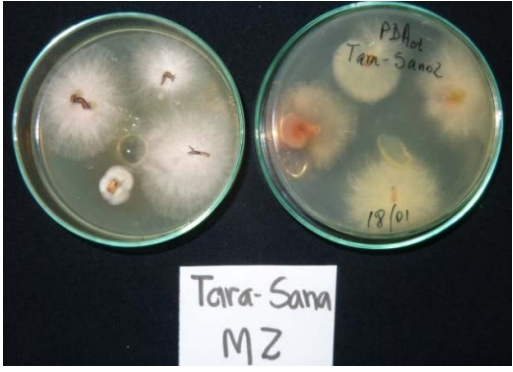

(b)



(d) 


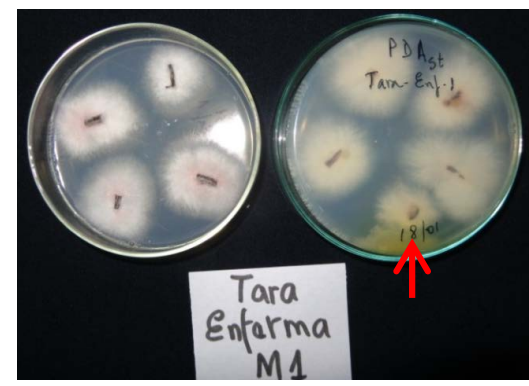

(e)

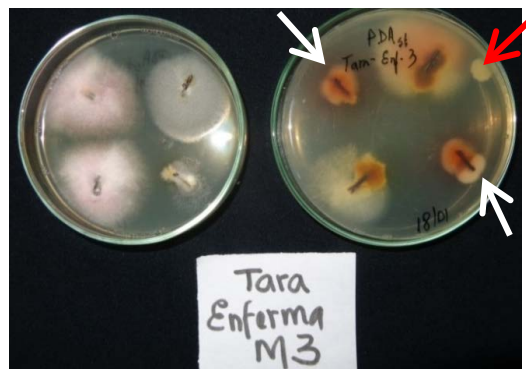

(g)

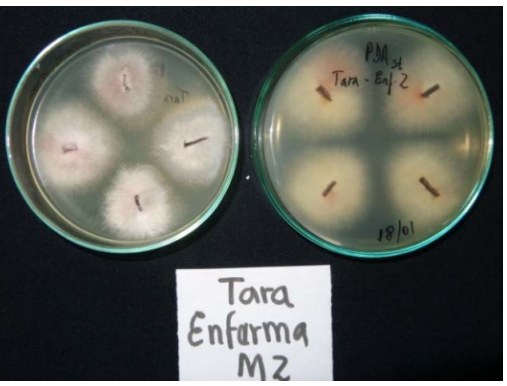

(f)



(h)

Figure 3. Growth on PDA of colonies derived from apparently healthy (a-d) and diseased (e-h) plantlets. Contaminant fungal colonies are marked with red arrows, and Cylindrocarpon sp. with white arrows.

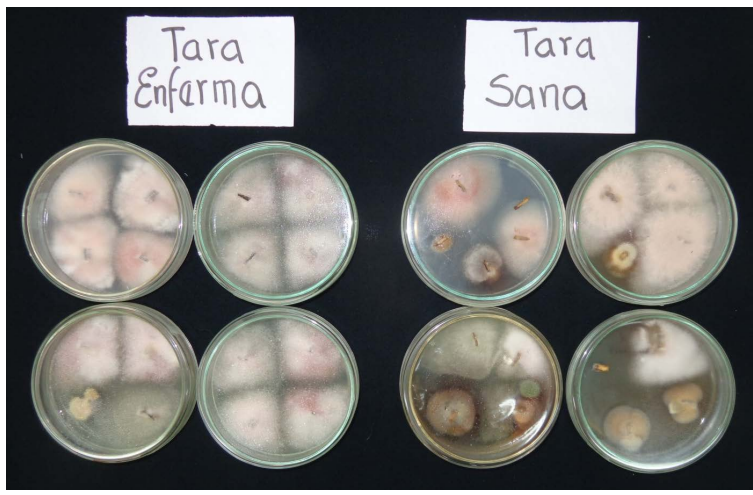

Figure 4. Growth of Fusarium sp. (clear pink = lilac colony) and Cylindrocarpon sp. (white arrow) on PDA, as derived from diseased (left) and apparently healthy (right) plantlets.

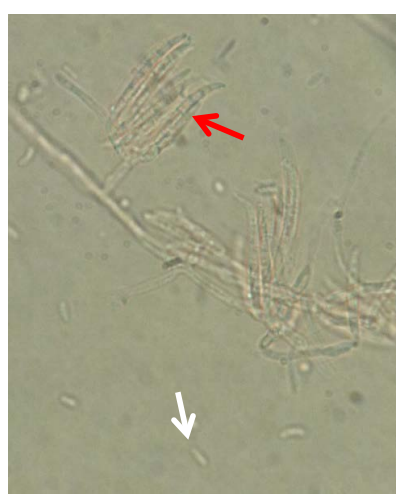

(a) 


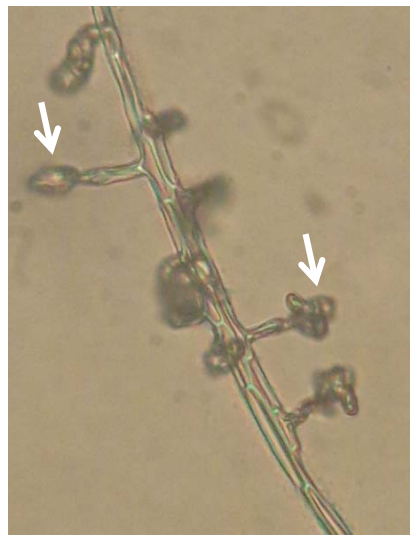

(b)

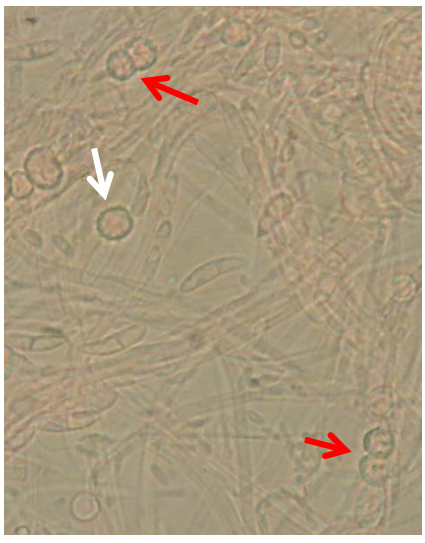

(c)

Figure 5. Morphological characteristics of F. oxysporum. (a) Macroconidia (red arrows), microconidia (white arrow) (400x); (b) Short monophialideswith false heads formed by microconidia (white arrow) $(400 \times)$; (c) Chlamidospore pairs (red arrow) and on their own (white arrow) $(400 \times)$.

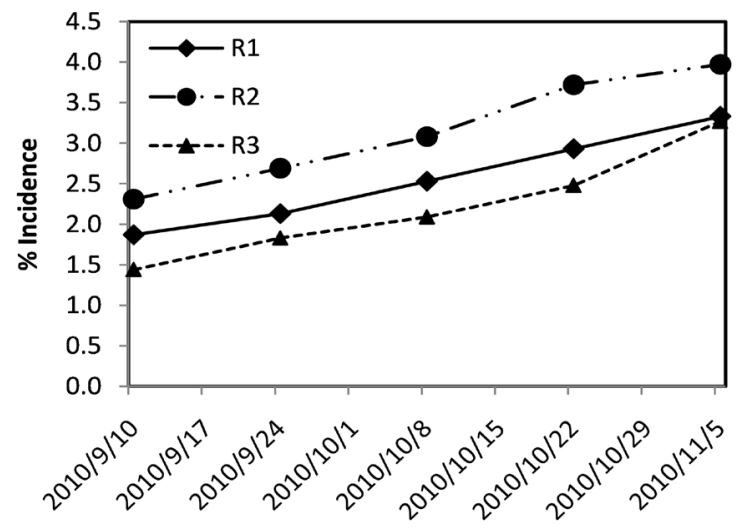

Assessment dates

(a)
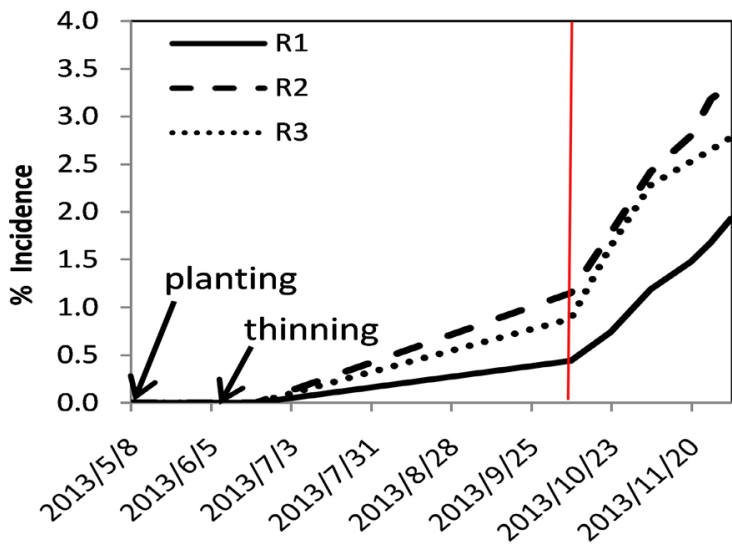

\section{Days after planting}

(b)

Figure 6. Disease progress curves for the incidence of wilting in taracaused by $F . o x^{-}$ ysporum. (a) 2010; (b) 2013. $\mathrm{R}_{1}=$ Plot 1 , approximately $600-700$ plantlets; $\mathrm{R}_{2}=$ Plot 2 , approximately $700-800$ plantlets and $R_{3}=$ Plot 3 , approximately $700-800$ plantlets. 


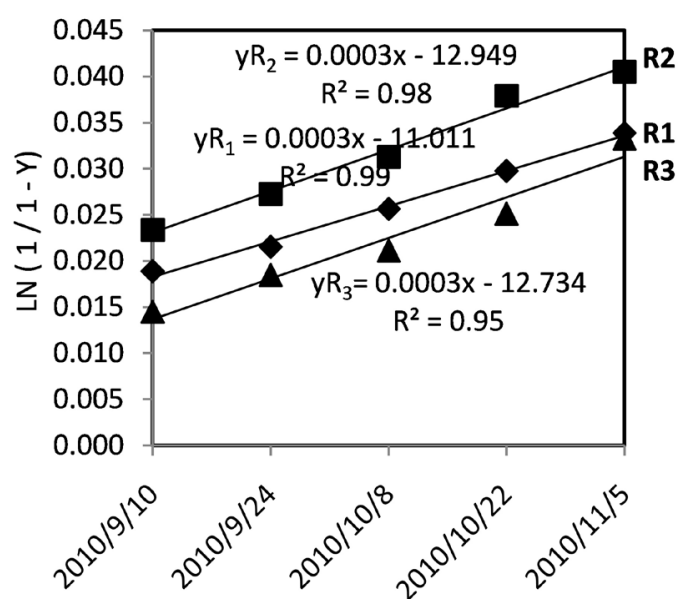

(a)

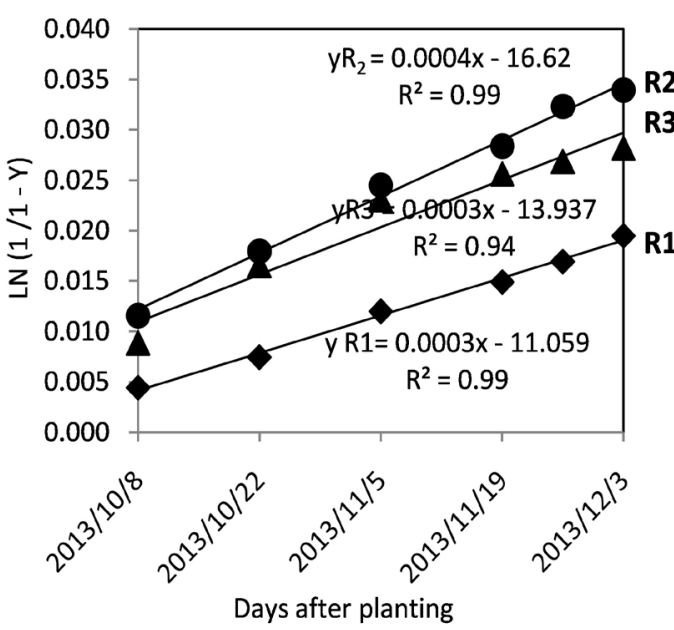

(b)

Figure 7. Linearization of the disease progress curves. (a) 2010; (b) 2013. $\mathrm{R}_{1}=$ Plot 1, approximately $600-700$ plantlets; $R_{2}=$ Plot 2 , approximately $700-800$ plantlets and $R_{3}=$ Plot 3, approximately 700 - 800 plantlets.

\section{Discussion}

The genus Fusarium contains plant pathogens that affect a wide range of plants, including banana, cotton, pulses, maize, rice, sorghum, barley and oats. In wheat, they are among the most commonly involved in crown, root, stem, grain and spike rot. They also cause vascular wilting in many other plants [7]. The present work shows $F$. oxysporum to cause wilting in tara.

The characteristic symptoms of wilting in tara include the initial yellowing and gradual reddening of the folioles, defoliation, vascular discolouring, dwarfism, degradation of the root system and death. These symptoms agree with those described by Agrios [8], who indicated F. oxysporum Schlechtto be commonly present in soil and to cause vascular wilting in a range of plants. Indeed, F. $o x$ ysporum is the most common cause of vascular wilting in a range of economically important crops [13]. This anamorphic species is characterised by a number of morphological criteria, including the shape of the macroconidia, the 
structure of the micro conidiophores, and the formation of chlamydospores [9]. The present isolates obtained from the roots of diseased and apparently healthy plants had a mild lilac colour, and under the microscope showed the characteristic macroconidia, conidiophores with short phialides and false heads, and chlamydospores (in pairs oralone) of $F$. oxysporum as described by Leslie and Summerell [6] and Summerell, Salleh and Leslie [7] (Figures 5(a)-(c)). F. oxysporum is characterised as a plant pathogen that affects a variety of cultivated annual and fruit plants [5]. Cylindrocarpon sp., a contaminant, was also isolated from some samples, as was Cylindrocarpon sp., another soil pathogen.

The progress curves for the incidence of wilting were similar in both study years, with meanprogress slightly greater $(0.7 \%)$ in 2010 , likely due to factors not measured in the present work. In a study on cotton (Gossypium hirsutum L.) wilting caused by F. oxysporum f. sp. vasinfectum Snyder and Hansen, Madden et al. [12] indicate that the increase in the number of infected plants over time is not caused by the plant-to-plant dissemination of the fungus, but rather by the inoculum present in the soil. Campbell and Madden [13] categorizes such diseases as monocyclic, i.e., in which there is a single infection cycle [14]. In the present work too, the source of infection would appear to be the soil. The propagules of $F$. oxysporumcan survive long periods in the soil in the absence of any host [13].

Campbell and Madden [13] indicates that monocyclic diseases can be described by monomolecular models. The most important variables in such models are the initial inoculum $\left(\mathrm{y}_{\mathrm{o}}\right)$, the apparent infection rate $(\mathrm{r})$, and the maximum incidence of the disease. These models have been used to describe the incidence of different epiphytes in annual crops such as lettuce wilt (Lactucasativa) caused by Sclerotinia minor, wheat root rot (Triticum sativum L.) caused byCochliobolus sativus [14], and lettuce wilt caused by Sclerotinia minor and $S$. sclerotiorum [15], etc. In the present work, the apparent infection rates for 2010 and 2013 were similarly low at $\mathrm{r}_{\mathrm{R} 1-\mathrm{R} 3}=0.0003$ /day and $\mathrm{r}_{\mathrm{R} 1-\mathrm{R} 3}=0.0003$ $0.0004 /$ day respectively. Other authors report similar values for monocyclic diseases caused by soil pathogens in annual plants [13] [14] [15]. These findings are compatible with F. oxysporum.

\section{Conclusion}

In conclusion, wilting in tara starts as a yellowing of the folioles, their gradual reddening, and after defoliation, decomposition of the root system, and finally death. Samples of all the plants examined, whether showing signs of disease or apparently healthy, produced fungal colonies on PDA. Given the morphology of these colonies, their ability to grow on PDA, their macroconidia, phialides and chlamydospores, the causal agent of wilting would appear to be F. oxysporum. The disease progress curve for the incidence of this disease in tara fits that of a monocyclic epiphyte, with low infection rates characteristic of soil pathogens. According to the results obtained, the wilting of tara could become an emerging 
disease in field plantations.

\section{Acknowledgements}

The author is grateful to ASDI-DICYT-UMSS for financial support for publishing this article. Thanks are also owed to the Banco de Semillas Forestales of the Escuela de Ciencias Forestales (BASFOR-ESFOR, Universidad Mayor de San Simon) for access to its nursery and the use of materials, the students (II/2013) of Forestry Plant Entomology and Pathology at the ESFOR for their help in field and laboratory work, and Adrian Burton for language and editing assistance.

\section{Conflicts of Interest}

The authors declare no conflicts of interest regarding the publication of this paper.

\section{References}

[1] Mancero, L. (2009) La Tara (Caesalpinia spinosa) en Perú, Bolivia y Ecuador: Análisis de la Cadena Productiva en la Región. Programa Regional ECOBONAIntercooperation, Quito.

[2] Cabello, I. (2009) Monografía para el cultivo de la tara Caesalpinia spinosa (Molina) Kuntze. Perú biodiverso, Lima, Perú, 32.

[3] Coca Morante, M. (2008) Principales enfermedades de la tara (Caesalpinia spinosa) Boletín técnico No 4. Facultad de Ciencias Agrícolas, Pecuarias, Forestales y Veterinarias “Dr. Martin Cárdenas”, Universidad Mayor de San Simón. Cochabamba, 4.

[4] Coca, M.M. and Sejas, G.D. (2014) Informe de aplicación de tratamientos para evaluación de control curativo en la enfermedad marchitamiento de la tara en plantación establecida en la localidad de La Aguada, Valle Grande, Departamento de Santa Cruz, Bolivia. Cochabamba, 3.

[5] Dean, R., Van Kan, J.A.L., Pretorius, Z.A., Hammond-Kosack, K.E., Di Pietro, A., Spanu, P.D., Rudd, J.J., Dickman, M.Y., Kahmann, R., Ellis, J. and Foster, G.D. (2012) Review: The Top 10 Fungal Pathogens in Molecular Plant Pathology. Mo lecular Plat Pathology, 13, 414-430. https://doi.org/10.1111/j.1364-3703.2011.00783.x

[6] Leslie, J.F. and Summerell, B.A. (2006) The Fusarium Laboratory Manual. WileyBlackwell, Hoboken, 306. https://doi.org/10.1002/9780470278376

[7] Summerel, B.A., Salleh, B. and Leslie, J.F. (2003) A Utilitarian Approach to Fusarium Identification. Plan Disease, 87, 117-128. https://doi.org/10.1094/PDIS.2003.87.2.117

[8] Agrios, G.N. (1996) Plant Pathology. Academic Press, St. Louis, MO.

[9] Roncero, M. (2003) Fusarium as a Model for Studying Virulence in Soilborne Plant Pathogens. Physiological and Molecular Plant Pathology, 62, 87-98. https://doi.org/10.1016/S0885-5765(03)00043-2

[10] Van Maanen, A. and Xu, X.-M. (2003) Modelling Plant Disease Epidemics. European Journal of Plant Pathology, 109, 669-682. https://doi.org/10.1023/A:1026018005613

[11] Shtienberg, D. (2000) Modelling: The Basis for Rational Disease Management. Crop 
Protection, 19, 747-752. https://doi.org/10.1016/S0261-2194(00)00099-5

[12] Madden, L.V., Hughes, G. and van den Bosch, F. (2007) The Study of Plant Disease Epidemics. The American Phytopthological Society, Saint Paul, MN.

[13] Campbell, C.L. and Madden, L.V. (1990) Introduction to Plant Disease Epidemiology. Wiley, New York.

[14] Beckman, C.H. (1987) The Nature of Wilt Diseases of Plants. American Phytopathological Society, Saint Paul, MN.

[15] Hao, J.J. and Subbarao, K.V. (2005) Comparative Analysis of Lettuce Drop Epidemics Caused by Sclerotinia minor and $S$. sclerotiorum. Plant Disease, 89, 717-725. https://doi.org/10.1094/PD-89-0717 